A manuscript for consideration in Biological Reviews

\title{
Lakes in the era of global change: moving beyond single-lake thinking in maintaining biodiversity and ecosystem services
}

\author{
Jani Heino ${ }^{1}$, Janne Alahuhta ${ }^{2}$, Luis Mauricio Bini ${ }^{3}$, Yongjiu Cai ${ }^{4}$, Anna-Stiina \\ Heiskanen', Seppo Hellsten' ${ }^{1}$, Pirkko Kortelainen', Niina Kotamäki', Kimmo T. \\ Tolonen $^{5}$, Petteri Vihervaara ${ }^{6}$, Annika Vilmi $^{1}$ \& David G. Angeler ${ }^{7,8}$ \\ ${ }^{1}$ Finnish Environment Institute, Freshwater Centre, Latokartanonkaari 11, FI-00790 Helsinki, \\ Finland. Correspondence: jani.heino@environment.fi \\ ${ }^{2}$ University of Oulu, Geography Research Unit, P.O. Box 3000, FI-90014 University of Oulu, \\ Finland. \\ ${ }^{3}$ Universidade Federal de Goiás, Departamento de Ecologia, Goiânia, GO, 74690-900, Brazil. \\ ${ }^{4}$ Key Laboratory of Watershed Geographic Sciences, Nanjing Institute of Geography and \\ Limnology, Chinese Academy of Sciences, 73 East Beijing Road, 210008 Nanjing, China. \\ ${ }^{5}$ University of Jyväskylä, Department of Biological and Environmental Sciences, P.O. Box \\ 35, FI-40014 Jyväskylä, Finland.
}

${ }^{6}$ Finnish Environment Institute, Biodiversity Centre, Latokartanonkaari 11, FI-00790 Helsinki, Finland.

${ }^{7}$ Swedish University of Agricultural Sciences, Department of Aquatic Sciences and Assessment, Box 7050, 75007 Uppsala, Sweden.

${ }^{8}$ University of Nebraska - Lincoln, School of Natural Resources, Lincoln 68583-0984, USA. 


\begin{abstract}
The Anthropocene presents formidable threats to freshwater ecosystems. Lakes are especially vulnerable and important at the same time because they cover only a small area worldwide but harbour high levels of biodiversity and contribute disproportionately to ecosystem services. Lakes differ with respect to their general type (e.g., land-locked, drainage, floodplain and large lakes) and position in the landscape (e.g., highland vs lowland lakes), which contribute to the dynamics of these systems. Lakes should be generally viewed as 'meta-systems', whereby biodiversity is strongly affected by species dispersal, and ecosystem dynamics are contributed by the flow of material and substances among locations in a broader waterscape context. Lake connectivity in the waterscape and position in the landscape determine the degree to which a lake is prone to invasion by non-native species and accumulation of harmful substances. Highly-connected lakes low in the land scape accumulate nutrients and pollutants originating from ecosystems higher in the land scape. The monitoring and restoration of lake biodiversity and ecosystem services should consider the fact that a high degree of dynamism is present at global, regional and local scales. However, regional and local monitoring may be plagued by unpredictability of ecological phenomena, hindering adaptive management of lakes. Although monitoring data are increasingly becoming available to study responses of lakes to global change, we still lack suitable integration of models for entire waterscapes. Research across disciplinary boundaries is needed to address the challenges that lakes face in the Anthropocene because they may play an increasingly important role in providing ecosystem goods and services in the future.
\end{abstract}

Keywords: biological diversity, ecosystem change, freshwaters, metasystem, monitoring, resilience, restoration. 


\section{INTRODUCTION}

The Anthropocene, our current era, witnesses the overwhelming impacts of humans on our planet's geology, climate and ecosystems (Steffen et al., 2011; Waters et al., 2016). Indeed, most ecosystems world wide, including freshwater ecosystems, are threatened by multiple anthropogenic stressors (Dudgeon et al., 2006; Vörösmarty et al., 2010; Reid et al., 2019; Albert et al., 2020). Lakes are no exception, as they are threatened, inter alia, by climate change, land use intensification, eutrophication, acidification, water abstraction for agricultural irrigation, and non-native species (Dudgeon et al., 2006; Smol, 2019). Understanding the resilience and recovery of lake communities and ecosystems to environmental change has thus emerged as an important research program from the perspectives of biodiversity conservation and ecosystem services (Angeler \& Drakare, 2013; Angeler et al., 2015).

Biodiversity and ecosystem dynamics are affected by land scape connectivity, which facilitates organisms' movements and abiotic flows among locations (Heino, 2013a; Mitchell, Bennet \& Gonzalez, 2013). Therefore, understanding the effects of anthropogenic stressors on biodiversity and delivery of ecosystem services to humans requires lakes to be considered as integral parts of terrestrial-aquatic ecotones (e.g., Soininen et al., 2015), parts of the drainage systems (e.g., Soranno et al., 1999), and as land scapes themselves (e.g., Vilmi et al., 2016). The idea that lakes are not isolated from their surrounding terrestrial environments or other freshwater ecosystems dates back to Stephen Forbes $(1887$, p. 77) who wrote: “The fluviatile lakes, which are much more numerous and important, are appendages of the river systems of the State, being situated in the river bottoms and connected with the adjacent streams by periodical overflows. Their fauna is therefore substantially that of the rivers themselves, and the two should, of course, be studied together." This idea underscored the 
importance of considering lakes as parts of the drainage system by means of connections between riverine and lacustrine systems.

More than a century after the idea of Forbes (1887), the position of lakes in the landscape was further conceptually explored by Riera et al. (2000), who emphasized that lakes vary in the degree of connectedness to other ecosystems. They stated that the spatial organization of lake districts is largely a sum of geomorphological history, which led them to introduce the concept of "lake order" (Table 1). They and others showed that the landscape position of lakes (i.e., lake order) contributes to understanding several abiotic and biotic characteristics (Soranno et al., 1999; Riera et al., 2000). For instance, human settlements and species richness of various taxonomic groups typically increase with lake order (Kratz et al., 1997; Riera et al., 2000; Lewis \& Magnuson, 2000). Moreover, highly-connected lowland lakes are exceptionally vulnerable to multiple stressors, resulting from human activities in the surrounding areas (Reid et al., 2019). Consequently, the concept of lake order integrates societal and biological aspects, essentially reflecting that lakes are combined social-ecological systems (Pope et al., 2014). The degree of connectivity to other aquatic systems along with the topographic position in the land scape is further underlying these ideas. Lakes should thus be considered as parts of larger waterscapes (Soranno et al., 2010), where the land scape of lakes rather than individual lakes becomes the focal unit for ecosystem studies (Cumming, 2011). Such a view beyond traditional single-lake thinking can be very useful for understanding the stability of entire waterscapes in a changing world (Fried-Petersen et al., 2020).

Lakes are not only hotspots of biodiversity, but they also provide essential and valuable ecosystem services to human existence and economies. These services include raw water supplies (e.g., household drinking water, irrigation and industrial use), food (e.g., mussels, fish and waterfowl), hydropower, pollution control, climate regulation, recreation, 
tourism and aesthetic values, as well as waterways for inland water navigation and transport (Baron et al., 2002; Millennium Ecosystem Assessment, 2005; Tranvik et al., 2009; Vilbaste et al., 2016). In addition, while biodiversity is often considered a regulator of ecosystem functions underpinning the delivery of ecosystem services, biodiversity itself can also be considered as an essential ecosystem service (Mace, Norris \& Fitter, 2012). As multiple ecosystem services of lakes are largely sustained by biodiversity and associated ecosystem functions, the degree of connectivity of lakes should be given due attention (Mitchell et al., 2013).

Recently, the concept of geodiversity, the diversity of Earth surface forms, materials and processes, has also been suggested as a potentially useful concept to understand, conserve and maintain biodiversity and ecosystem services (Brilhaa et al., 2018; Schrodt et al., 2019). Positive relationships have been observed between biotic (biodiversity) or abiotic (geodiversity) attributes and ecosystem service supplies, suggesting that enhancement of joint biodiversity and geodiversity conservation generally should improve production of ecosystem services (Nelson et al., 2009; Cardinale et al., 2012; Harrison et al., 2014; Isbell et al., 2017; Alahuhta et al., 2018). This approach may also be useful in freshwater ecosystems (Kärnä et al., 2019; Toivanen et al., 2019).

In this review, we focus on lakes as integral parts of drainage basins, which is the basic tenet of landscape limnology (Kling et al., 2000). This idea is also associated with two central concepts in spatial ecology: metacommunities (Leibold et al., 2004) and metaecosystems (Loreau, Mouquet \& Holt, 2003). Owing to different levels of connectivity, topography and other features, comparing sets of land-locked lakes, drainage lakes, floodplain lakes and large lake systems is deemed a suitable approach (Table 1). This approach facilitates 'waterscape thinking' in understanding and managing lake biodiversity and ecosystem services from a land scape limnology perspective (Soranno et al., 2010). First, 
we therefore examine physical connectivity and movements of organisms and material among lakes. We will also consider terrestrial-aquatic and river-lake linkages when it comes to understanding metacommunity and meta-ecosystem dynamics in standing waters. Second, we focus on lake ecosystem services, emphasising how they can be understood in a broader context of waterscapes. Third, we integrate waterscape thinking in the monitoring and management of lakes. Finally, we discuss key ideas for future studies and implications for the management of biodiversity and ecosystem services of lake ecosystems in the Anthropocene.

\section{LAKES AS WATERSCAPES UNDERLYING THE MOVEMENT OF ORGANISMS AND MATERIAL}

Organisms typically disperse from one locality to another during their life cycle. When there is a strong potential for such between-site exchanges of organisms, the set of local communities forms a 'metacommunity', an idea that integrates processes occurring at multiple spatial scales (Leibold et al., 2004). Metacommunity organization thus results from different processes shaping local communities. In theory, local communities within a metacommunity can be structured by neutral processes and environmental filtering (Winegardner et al., 2012). The idea of a neutral assembly process is based on the hypothesis that all species are similar in their traits and abilities to survive, and local communities are thus mainly structured by neutral processes of evolution and relocation of species (Hubbell, 2001). Conversely, environmental conditions may, to different degrees, structure local ecological communities. The degree to which environmental factors affect the formation of local communities is directly linked to dispersal rates. Dispersal may be limited, sufficient or very high (Winegardner et al., 2012). In theory, if dispersal is limited, local community structure tends to deviate from what could be expected based on local abiotic and biotic 
environmental conditions alone (Martiny et al., 2006). Sufficient dispersal, in turn, enables species to reach suitable habitat patches, leading to species sorting along environmental gradients (Leibold et al., 2004). Lastly, if dispersal rates are very high, the environmental signal in community composition tends to be masked, and species may occur in suboptimal habitats due to strong source-sink dynamics (Mouquet \& Loreau, 2003; Kneitel \& Miller, 2003; Shmida \& Wilson, 1985; Pulliam, 1988).

Lakes are good model systems to examine metacommunity patterns and underlying processes, as they are environmentally highly heterogeneous and biologically diverse (Cottenie et al., 2003; Heino et al., 2017). They represent the targets for moving organisms, surrounded by inhabitable terrestrial habitats for many aquatic species. Consequently, different metacommunity dynamics may exist across different lake types, including landlocked lakes, drainage lakes, floodplain lakes and single large lakes (Table 1). In the following, we will consider the main features of each lake ecosystem type when it comes to understanding metacommunity and meta-ecosystem dynamics in waterscapes (Fig. 1).

One can assume that land-locked lakes, being relatively isolated from each other in the landscape, show limited exchange of organisms and should thus show high variation in community composition between lakes due to dispersal limitation (Heino et al., 2015). Interestingly, recent studies have shown that species sorting is still the main mechanism structuring local communities across land-locked lakes, at least across those showing seasonal filling and drying (Castillo-Escrivà et al., 2016; Maloufi et al., 2016). In order to track spatial and temporal changes in environmental conditions among land-locked lakes, organisms have to be efficient dispersers. However, dispersal abilities vary between organismal groups (Bilton, Freeland \& Okamura, 2001), and different groups may therefore show different metacommunity dynamics even across land-locked standing waters (De Bie et al., 2012). Species sorting along environmental gradients may be prevalent for strong dispersers, 
whereas weak dispersers can be assumed to be more dispersal limited across sets of land locked lakes (Heino, 2013b).

Compared to land-locked lakes, metacommunity organization should be different for drainage lakes connected by the riverine network. In these drainage lakes, dispersal between localities may not be as limited as in land-locked lakes, and even obligatory aquatic organisms, such as fish, may be able to disperse from one lake to another through connecting rivers and streams (Tonn \& Magnuson, 1982; Olden, Jackson \& Peres-Neto, 2001). Such increased connectivity may dictate that dispersal is an important mechanism in the assembly of drainage lake communities, which can be observed as rapid recolonizations of denuded lakes after physical (e.g., winterkill) or biotic (e.g., predation) disturbances (Tonn \& Magnuson, 1982; Magnuson et al., 1998). However, previous research has shown that ecological communities in drainage lakes are also mainly structured by species sorting (Cottenie et al., 2003; Alahuhta et al., 2015). These findings may stem from the fact that drainage lake systems offer ideal habitats for many organisms regarding both environmental conditions and dispersal pathways, contributing to the resilience of these systems to natural and anthropogenic disturbances (e.g., Truchy et al., 2015). Research on land-locked and drainage lakes, therefore, partly challenges basic predictions of a higher importance of dispersal limitation in the case of land-locked lakes and a lessened importance of species sorting (due to the high dispersal rates) in the case of drainage lakes (Heino et al., 2015).

Floodplain lakes are good examples of waterscapes where temporally changing hydrological conditions and subsequent connectivity to the riverine system drive local community dynamics (Junk, Bayley \& Sparks, 1989; Thomaz, Bini \& Bozelli, 2007). For example, during the flood period with increasing connectivity, floodplain lakes may be affected by high dispersal rates (Thomaz et al., 2007; Bozelli et al., 2015), while species sorting (e.g., Simões et al., 2013) and dispersal limitation may be more important during the 
dry phase (e.g., Petsch, Pinha \& Takeda, 2016). This is because the local communities become continuously more and more disconnected from the riverine systems with extended dry periods, which affects the assembly mechanisms of local communities (e.g., Fernandes et al., 2014). Studies on fish, macroinvertebrate, zooplankton, phytoplankton and macrophyte communities have evidenced such patterns in tropical and subtropical areas, although the specific details of these findings are often affected by species' dispersal abilities and presumably other biological traits (Fernandes et al., 2014; Padial et al., 2014; Dias et al., 2016; Petsch et al., 2016). The role of hydrological connectivity on local communities of floodplain lakes is emphasized because, in general, spatial variation in community composition is higher during low-water than during high-water periods. However, opposite patterns have also been detected (Angeler et al., 2010), which highlights the complexity that underpins community assembly in highly dynamic freshwater ecosystems (Datry et al., 2016).

Large lake systems, including the world's largest lakes (Herdendorf, 1982), are even more physically connected systems than floodplain lakes. Within large lakes, dispersal rates between localities may be so high that they override the influences of local habitat conditions, thus profoundly affecting local community dynamics. In such situations, the importance of habitat conditions for community composition may be reduced to a large extent, resulting in local communities being spatially structured and possibly at least partly homogenised by efficient dispersal (Vilmi et al., 2016; Cai et al., 2017; Tolonen et al., 2017). These patterns may emerge because high dispersal rates mediated by currents and wind in an environment with no apparent physical barriers should attain a more influential role than local environmental conditions in metacommunity organization in large lake systems.

Scale-dependency of metacommunity patterns is also a typical finding in empirical studies of lakes. For example, Soininen et al. (2011) found that inferences regarding assembly mechanisms of lake bacterioplankton, phytoplankton and zooplankton communities were 
dependent on spatial extent. It is possible that dispersal limitation attains a larger role across than within drainage systems, whereas species sorting is more important within drainage systems because most species are able to disperse among sites within a short temporal window (Heino et al., 2015). Partly in line with this reasoning, a recent study focussing on the assembly of 10 distinct organismal groups (from bacteria to fish) within and across four separate floodplains in Brazil suggested increasing importance of dispersal limitation with increasing spatial extent (Lansac-Tôha et al., unpublished). However, despite the broadly recognized importance of spatial scale for understanding ecosystem patterns and processes (Heino, 2011; Allen et al., 2014), no studies have explicitly compared scale-dependency of metacommunity patterns across different types of lakes, including land-locked, drainage, floodplain and large lake systems.

Similar to metacommunities, a set of different types of lakes may also act as a metaecosystem or as a terrestrial-aquatic ecotone. For example, lakes exchange organisms (e.g., emerging aquatic insects) and material (e.g., riparian-based leaf litter inputs to lakes) with terrestrial ecosystems, which affect the dynamics of both ecosystems (Scharnweber et al., 2014; Soininen et al., 2015). This idea is also broadly related to catchment geodiversity, whereby abiotic features of a catchment affect biological communities and may further act as a surrogate for biodiversity in lakes (Iversen et al., 2019; Toivanen et al., 2019). In addition, exchanges of organisms and material occur between riverine and lacustrine ecosystems, which may be important for supplying and replenishing resource bases and biological communities in lakes (Ward, Tockner \& Schiemer, 1999; Tockner et al., 1999). This is typical, for example, in riverine floodplain systems in tropical and subtropical areas (e.g., Junk et al., 1989).

Finally, besides natural material and organisms that are typically distributed between ecosystems, different lake locations may also exchange anthropogenically-derived materials. 
For example, strong winds may contribute to toxic algal blooms in large lakes (e.g., Wu et al., 2015), distribute large amounts of microplastic in lake surface waters (e.g., Fischer et al., 2016), and the hydrologic conditions of the receiving water body may affect the distributions of drug concentrations (e.g., Metcalfe et al., 2003). In addition, movements of humans in waterscapes (e.g., boating, canoeing and fishing) are known to distribute invasive species among locations, which may have drastic effects on biodiversity (Johnson, Ricciardi \& Carlton, 2001; Cambray, 2003; Rahel, 2007; Kelly et al., 2013). The distributions and routes of contaminants, pollutants and invasive species are fund amental abiotic and biotic agents of global change and thus require more attention from a meta-ecosystem perspective. Therefore, considering lakes as parts of waterscapes rather than focussing on each lake separately at a time would increase our understanding of major local and regional phenomena, which underlie lake ecosystem services and anthropogenic stressors impacting lakes (see Section 3).

\section{LAKE ECOSYSTEM SERVICES: SOCIO-ECONOMIC VALUES AND THREATS TO THEIR SUPPLIES IN WATERSCAPES}

Mapping and socio-economic valuation of freshwater ecosystem services have so far been scarce compared to terrestrial systems. The review of Egoh et al. (2012) revealed that less than $5 \%$ of ecosystem service indicators apply to freshwater ecosystems. Furthermore, in the "The Economics of Ecosystems and Biodiversity" (TEEB) ecosystem service valuation database (Van der Ploeg \& de Groot, 2010), less than 1\% of datasets are from lakes and rivers. Therefore, mapping and valuing ecosystem services of freshwaters comprise a research gap to be filled in the future, especially in the context of waterscape thinking. In the following, we discuss several examples that emphasize different lake ecosystem service types. Although these examples are not exhaustive, they present a common thread that links 
together lake ecosystem services and human impacts that affect waterscapes directly and indirectly. They are also simultaneously linked to context-dependent management challenges in the waterscape context (See Section 4).

\subsection{Lake fisheries and aquaculture}

One important ecosystem service provided by lakes is related to fisheries. Catches in freshwater systems are continuously increasing, especially in Asia and Africa (Welcomme et al., 2010; Jia, Zhang \& Liu, 2013), at the same time when marine fish stocks and catches are declining (Coll et al., 2008; Pauly \& Zeller, 2016). The importance of freshwater fish as a source of animal protein for humans is globally among the highest after marine fish, pig, chicken and cattle meat (Welcomme et al., 2010). Commercial, domestic and recreational fisheries significantly contribute to food security, employment, nature-related enjoyment and economies around the world (Butler et al., 2009; EU, 2011; McIntyre, Lierman \& Revenga, 2016). Therefore, freshwater fisheries are economically significant from local to global scales

(Table 2). Recreational fisheries are important to human well-being, as well as to local and national economies (Cowx, Arlinghaus \& Cooke, 2010; Melstrom \& Lupi, 2013; Pope et al., 2014). Future sustainability of freshwater fisheries is, however, threatened by many human impacts that include direct and indirect effects of climate change (Ficke, Myrick \& Hansen, 2007; Comte et al., 2013), eutrophication (Diekmann et al., 2005; Dodds et al., 2009), pollution, introduced species, parasites, diseases (FAO, 2018; Reid et al., 2019) and overfishing (Allan et al., 2005; Carpenter, Stanley \& Vander Zanden, 2011).

In many parts of the world, freshwater aquaculture is an important cause of species introductions and water quality deterioration that extends beyond the area where this activity is done (Rist et al., 2014). These observations reinforce the need to consider the 
interdependency among freshwater ecosystems and to aband on the view of the isolation of a lake ecosystem. Thus, understanding the impacts of different stressors on fisheries and the impacts of aquaculture to lakes would benefit from increased focus on lakes as parts of waterscapes. This is because the fish yield provided by a single lake may, for example, also be dependent on the movement and recovery of a target fish species from other lakes after a disturbance event (Tonn \& Magnuson, 1982; Magnuson et al., 1998).

\subsection{Recreational activities associated with lakes}

Many recreational outdoor activities are associated with lakes and other inland waters (Table

2). These outdoor activities, including swimming, canoeing, wind surfing, boating, cruisetourism, angling, birdwatching and holidaying, are important for human well-being and economies (Xie, 2012; Reconomics Plus, 2017; Mackintosh, Griggs \& Tate, 2019). However, eutrophication, pollution, climate change, spread of invasive species, and their undesirable side effects (e.g., increased prevalence of harmful algal blooms) are diminishing recreational and lakefront property values (Dodds et al., 2009). For instance, cyanotoxins pose serious threats to human health (Caller et al., 2009) and aquatic food webs (Ferrão-Filho \& Kozlowsky-Suzuki, 2011; Reid et al., 2019). Similarly, the increasing incidence and magnitude of blooms of raphidophcean flagellates (Gonyostomum semen) has several socioecological repercussions, including skin irritation in swimmers and drinking water quality degradation (Angeler, Allen \& Johnson, 2012).

Many recreational outdoor activities are also dependent on how people can access particular lakes. Water bodies close to human settlements have higher potential to offer recreational ecosystem services than lakes faraway, simply because people cannot reach remote lakes so easily (Ala-Hulkko et al., 2016). However, lakes suffer anthropogenic 
pressures due to local, regional and global environmental change, which often hinders the quality and quantity of recreational outdoor activities in lakes reachable to people. Thus, although the relationship between the recreational values and ecological status of lakes is not straightforward (Ziv et al., 2016), recreational ecosystem services provided by lakes are best supplied through balancing between sustainable accessibility by public transportation to reach inland waters and maintaining moderate or high level of naturalness of lakes.

Along with positive effects of recreational activities on humans, there are also potential harmful impacts on lakes. For example, canoeing, boating and cruise-tourism are likely to spread invasive species when moving from one lake to another or between distant locations in a large lake system (Johnson \& Padilla, 1996; Johnson et al., 2001). Although these harmful impacts may be difficult to prevent, they should be considered when planning the focus on lakes where those recreational activities are freely allowed. In a waterscape context, it would be desirable to preserve parts of large lake systems or certain individual lakes where recreational activities are limited. These locations could act as havens of biodiversity from which colonisations to more human-influenced lakes are possible.

\subsection{Water as a resource}

Lakes are crucial supplies of drinking and household water for millions of people worldwide (Delpla et al., 2009; Qin et al., 2010). However, the quality, quantity and availability of these resources are threatened due to various reasons. Climate change is predicted to increase temporal and regional variation in precipitation, causing regional scarcity (or increase) of water resources for ind ustry, agriculture and households (Bangash et al., 2013; Donnelly et al., 2017). The quality and quantity of water supplies for human usage are already being harmed by climate change, pollution, eutrophication and overuse of lake water for 
agricultural irrigation (Delpla et al., 2009; Whitehead et al., 2009; Qin et al., 2010). Poor quality of water increases the costs of water treatment and may even prevent the usage of water by humans (e.g., Qin et al., 2010). Sewage water treatment plants are also nowadays facing novel challenges, as improved detection and analysis techniques indicate that aquatic systems receive a variety of pollutants. For instance, traces of micropollutants, medicines and illicit drugs appear in water samples taken from lakes that receive high amounts of treated waste-waters (Metcalfe et al., 2003; Berset, Brenneisen \& Mathieu, 2010; Guo et al., 2014). Furthermore, an increasing body of evidence shows that, in addition to oceans, also lakes receive notable amounts of microplastic pollution (Fisher et al., 2016; Mason et al., 2016). Microplastic particles eventually accumulate in the food web through ingestion by animals (Browne et al., 2008; Setälä, Fleming-Lehtinen \& Lehtiniemi, 2014). Again, considering lakes as integral parts of waterscapes would help in tracing and predicting the potential sources and impacts of pollution at the level of an individual lake and beyond.

\subsection{Hydropower production}

Dams built for providing hydropower are increasingly being planned over the world (Zarfl et al., 2015; Lees et al., 2016). Hydropower production has strong negative trade-offs with other ecosystem services through decreased connectivity, thereby threatening freshwater biodiversity and fisheries (Ziv et al., 2012; Wieser, 2019). The social and ecological impacts of hydroelectric dams on upper and lower reaches of rivers have been recognized for a long time (Baxter, 1977; Hellsten et al., 1996). However, these impacts can be even more detrimental in tropical, near-pristine flood plain-river systems (Lees et al., 2016; Anderson et al., 2018). The impacts on floodplain lakes upstream from dams are sharp and unequivocal because these environments are permanently flooded by the impoundment. Downstream 
impacts are also severe because flow regulation disturbs the seasonal flood pulse, a key process maintaining biodiversity and ecosystem services in floodplain systems (Arantes et al., 2019). This is also a prime example of meta-ecosystem thinking, being in this specific example related to the river-floodplain linkages, disrupted by damming in a broader waterscape.

\subsection{Regulating services associated with lakes}

The relative importance of lakes (per unit area) in climate regulation has been classified to be high (Millenium Ecosystem Assessment, 2005; Downing, 2006). Indeed, important roles of lakes in climate regulation have been supported by several studies (Downing et al., 2008; Tranvik et al., 2009; Williamson et al., 2009; Le Quéré et al., 2015). Most of the displaced organic carbon (C) from terrestrial systems is buried in the sediments of freshwater lakes and coastal systems, representing short-term to long-term sequestration of atmospheric $\mathrm{CO}_{2}$, whereas the significance of open ocean sediments in carbon burial is much lower (Downing et al. 2008; Tranvik et al. 2009; Le Quéré et al., 2015).

Lakes modify the terrestrially-fixed carbon transport to the coast by both evading $\mathrm{CO}_{2}$ to the atmosphere and sequestering $\mathrm{C}$ in the sediments. Thus, both areal $\mathrm{C}$ evasion and $\mathrm{C}$ burial are larger in small lakes compared to large ones (Algesten et al., 2003; Kortelainen et al., 2004; Kortelainen et al., 2006a; Cole et al., 2007). In the boreal zone, for example, the majority of $\mathrm{C}$ in freshwaters is in a dissolved form (DOC) (Mattsson et al., 2005; Kortelainen et al., 2006b), resulting in lower $\mathrm{C}$ burial compared to regions where particulate fraction dominates. Furthermore, $\mathrm{C}$ evasion to the atmosphere in boreal lakes is often larger compared to permanent $\mathrm{C}$ burial in sediments (Algesten et al., 2003; Kortelainen et al., 2004;

Kortelainen et al., 2006a). At the land scape scale, the role of small lakes was emphasized in 
net $\mathrm{C}$ accumulation, whereas the role of large lowland lakes as releasing $\mathrm{CO}_{2}$ to the atmosphere was pronounced (Einola et al., 2011). However, the role of lakes in landscapescale $\mathrm{C}$ cycling in a changing climate is still highly uncertain (e.g., Anas et al., 2015).

Bastviken et al. (2011) estimated that the emissions of $\mathrm{CH}_{4}$ from freshwaters correspond to at least $25 \%$ of the terrestrial carbon sink. Lakes emit methane through several pathways, including bubble flux from the sediments, diffusive emissions and plant-mediated emissions through emergent macrophytes (Bastviken et al., 2004). $\mathrm{CH}_{4}$ emissions from hydroelectric reservoirs may also be significant because methane is released during water passage through turbines (Kemenes, Forsberg \& Melack, 2007; Barros et al., 2011). Even though methane leakage is augmented by emergent macrophytes, $\mathrm{CH}_{4}$-release from the lakes is also biologically controlled by methanotrophic bacteria (Schubert et al., 2010; Borrel et al., 2011; Oswald et al., 2016). All these studies indicate a prominent role of lakes in global carbon budgets, especially considering their small coverage of the earth surface (Table 2). Lakes have been observed to be both sinks and sources of greenhouse gases, yet the role in carbon cycle varies greatly depending on the characteristics of the lake, its catchment and local climate conditions (Bastviken et al., 2004; Downing et al., 2008; Tranvik et al., 2009; Bastviken et al., 2011).

The Millennium Ecosystem Assessment (2005) emphasised that regulating ecosystem services may be the most valuable ones. Pollution control capacity of lakes and buffering effects of lake-margin wetlands through retention and sedimentation of nutrients and pollutants is an important regulating ecosystem service particularly in protecting downstream waters within the catchments (Simonit \& Perrings, 2011; Vilbaste et al., 2016). In the littoral zone, pollution control capacity and nutrient retention are generally boosted by aquatic macrophyte beds and periphyton growth (Petticrew \& Kalff, 1992; Dodds, 2003). The balance between nutrient retention and internal loading in lakes is affected by lake trophic 
status, whereas nutrient balance is dominated by retention in oligotrophic temperate lakes and by internal loading in eutrophic lakes (Søndergaard, Jensen \& Jeppesen, 2001).

\section{MANAGING LAKES IN THE WATERSCAPE CONTEXT IN A NON- STATIONARY WORLD}

Environmental factors, habitat connectivity and movements of organisms and material are major factors shaping lake communities and ecosystems in waterscapes (see Section 2). However, it is becoming increasingly evident that global environmental change fund amentally alters disturbance regimes that can alter ecological communities (e.g., species invasions and extinctions) and abiotic templets (e.g., habitat fragmentation, ecotone boundaries, and the magnitude, frequency and duration of floods and droughts), and ultimately ecosystem service provisioning (Albert et al., 2020). Because many of these factors extend beyond individual lakes, management, restoration and conservation of lakes need to embrace a wider waterscape perspective (Soranno et al., 2010; Fried-Petersen et al., 2020). In this section, we focus on several challenges related to the management of lakes in a waterscape context. We particularly embrace the resilience perspective (Holling, 1973; Table 2). This perspective refers to tipping points, alternative system regimes and non-stationary changes (Baho et al., 2017), which complicate adaptive and transformative management of lakes in a rapidly changing world. Lakes are perhaps among the best-studied ecosystems regarding the phenomena of resilience and alternative regimes (Scheffer et al., 1993), which provides opportunities to extend the discussion from the local lake ecosystem level to that of entire waterscapes. This approach is thus associated with the resilience thinking in a spatially explicit way (Allen et al., 2016; Sundström et al., 2017). 
The capacity of ecosystems to absorb disturbances is limited, and they can thus undergo profound abiotic and biotic changes once a disturbance threshold is passed. There are many examples of lakes that have changed from a desired clear-water regime to an undesired algal-d ominated regime due to eutrophication (Carpenter, 2003; Bicudo et al., 2007), and such changes are especially common in agricultural waterscapes. Inherent in such shifts is the loss of recreational values (e.g., fisheries, swimming and boating) and biodiversity change. Once stabilized in degraded regimes, lakes in agricultural waterscapes will not return to the clear-water state in the absence of significant, long-lasting and costly management. Furthermore, new system regimes are often hysteretic, meaning that the energy required for returning them to a previous regime is substantially higher than the energy that pushed the system into its alternative regime. This hysteresis is often responsible for the difficulty to break the feedbacks of a degraded system, which hinders their return to the previous regime (Suding, Gross \& Houseman, 2004). There is a large body of lake biomanipulation studies documenting restoration failures due to this difficulty (Gulati, Pires \& Van Donk, 2008).

At least two fundamental implications arise from lake resilience research that are crucial to our understanding and management of lakes as parts of waterscapes. First, regime shifts in lakes contrast with the assumption that ecosystems recover after disturbances have ceased, eventually reaching pre-disturbance equilibrium or approach arbitrarily defined reference conditions if given enough time. Such a view is rooted in classical ecological stability research, which considers a balanced (i.e., ecosystems recover their balance after disturbances) rather than a discontinuous (i.e., non-linear regime changes) view of ecosystems (Allen et al., 2019). Second, defining reference conditions per se is problematic because even reference states change, both locally and regionally, which complicates assessments of recovery (Duarte et al., 2009). This was exemplified by McCrackin et al. (2017) who estimated that, depending on the biological group (e.g., algae, submerged 
macrophytes, invertebrates and vertebrates) or ecosystem function (e.g., nitrogen, phosphorus and carbon cycling), recovery times after control of nutrient inputs ranged from $<1$ year to approximately a century. However, assuming recovery at the scale of centuries can be erroneous because changing ecological baselines due to anthropogenic environmental change often manifest at decadal time scales. More specifically, rapid environmental change may outpace the attainment of recovery targets, which thus become obsolete. Such a phenomenon is again indicative of non-stationary change (Table 1), which can be further demonstrated with the current debate concerning recovery of surface waters from acidification. Scientists and managers frequently embraced a stationary view that lake ecosystems have not had enough time to recover biologically since the implementation of acidification mitigation measures in the 1970s and 1980s. This contrasts with non-stationary viewpoints. Research has shown that recovery can be masked because of abiotic (e.g., decreased water transparency) and biotic (e.g., algal expansion and bloom formation) factors. These factors may not necessarily be directly related to acidification and may alter the ecological baselines of both acidified and reference lakes relatively fast (Angeler \& Johnson, 2012). Such nonstationary interpretations are also echoed in hypotheses about acidified lakes comprising stable degraded regimes from which biotic and abiotic recovery to a circumneutral regime equivalent is unlikely (Baho et al., 2014).

In the face of non-stationary change, managers often have to rely on mitigating the impacts when restoration is unfeasible. This can have crucial implications for sustainable management of lakes in the long term because the amount of management needed may strongly vary and potentially increase over time (Angeler et al., 2020). However, our ability to manage lakes locally, let alone in entire waterscapes, is inadequate. This suggests that long-term costs and benefits need to be carefully compared against the potential harm that can arise from management itself. For example, if lake management targets the optimization of 
specific ecosystem services (e.g., commercial fisheries), the result may be loss of resilience (Holling \& Meffe, 1996). Therefore, the management of waterscapes has a strong uncertainty component, meaning that many future challenges are unknown and cannot be envisioned in the context of current practices (Angeler et al., 2020).

Managing waterscapes for specific sets of ecosystem services may require deliberate transformations for a sustainable future (Hobbs et al., 2009). However, implementing such a management strategy is difficult owing to the scales and dimensions (e.g., ecological, social, economic and legal) that need to be considered in a waterscape context. The implication is that despite exhaustive adaptive experimentation and knowledge acquisition, we are unlikely to know enough to intentionally create desired waterscapes that are self-organizing and selfmaintaining in a rapidly changing world (Baho et al., 2017). Also, a major limitation of such intended transformation is our lack of knowled ge of what a novel, future, viable and selforganizing ecosystem should look like (Murcia et al., 2014), although scenario planning could be useful for this purpose (Kok et al., 2017). Given the reality of non-stationary change, management goals related to deliberate transformations of waterscapes to maintain biodiversity and ecosystem services may thus become unrealistic. Hence, there is a need for consistent management in the form of human-provided inputs to maintain feedbacks, although such waterscapes might potentially have low resilience and be potentially exposed to unintended management side-effects or indirect social dynamics (Angeler et al., 2020).

Lake liming has been implemented to counteract acidification effects and mimic conditions of circumneutral lakes in Northern Europe and North America (Henriksson \& Brodin, 1995; Sandoy \& Romunstad, 1995). Rather than restoring a circumneutral regime, liming only mimics such conditions. Specifically, liming forces the acidified regime to approximate lake conditions that are conducive to ecosystem service provisioning (e.g., recreational fishing and aquaculture). Liming is done to manage for the ghost of a past 
circumneutral lake regime (Angeler et al., 2020). The fact that liming is a form of coercive management is manifested in the ultimate return of acidic conditions once liming is ceased (Clair \& Hindar, 2005). In biodiversity conservation and restoration contexts, liming is increasingly viewed as detrimental due to its considerable alteration of biogeochemical and biological features of lakes (Angeler et al., 2017). This example indicates that substantial negative side effects can arise when management is based on approaches aimed at maintaining a ghost of a past circumneutral regime; that is, a regime that is no longer maintainable without massive management. The liming example shows a fundamental challenge for the sustainable management of waterscapes in a rapidly changing world.

Finally, the degree to which fundamental science translates into the arena of environmental and sustainable development action will vary, highlighting complicated questions of who or what benefit from lake management and who or what is marginalized (Blythe et al., 2018). These are critically important questions for addressing the need to manage waterscapes for desired human outcomes. Rather than relying on intended transformation of sets of lakes to desirable and self-organizing waterscapes, even increasing amounts of management are required to satisfy the growing demands of ecosystem services for a growing human population. The resilience of ecological systems that is based on a large degree on human-induced management is considered fragile because of the lack of ecologically-based self-reinforcing feedbacks (Rist et al., 2016). Because management is contingent on environmental law (Twidwell et al., 2019), considerable policy implications arise from such uncertainty. Events from the past, such as spread of agriculture, that led to regime shifts in lakes and required extensive management to mitigate human-caused eutrophication (Carpenter, 2005), may provide lessons for the future. Such lessons could form the cornerstone for novel thinking about the complexity associated with the sustainable management of lakes in a waterscape context. 


\section{WHERE TO GO FROM HERE?}

Based on the evidence and ideas summarised above, there are a number of important avenues for future research and management of lakes that should help to fill knowledge gaps. The following four key gaps should thus be addressed in studies that integrate current knowledge about local and regional factors that dictate the ecology of individual lakes and broader waterscapes. This will also entail a systemic understanding of their resilience and how this resilience influences biodiversity and ecosystem services.

\subsection{An assessment of regime shifts at local, regional and global scales}

These evaluations should build on assessing early warning signals based on multiple lines of evidence (Wang et al., 2012; Spanbauer et al., 2014), and focus on the effects of climate warming, land use change, increases of dissolved organic carbon, alien species invasions and recovery from acidification on lake communities and ecosystems. These stressors may be acting individualistically or jointly. One should also keep in mind that the effects of multiple stressors accumulate to low-lying and highly-connected lakes, which are usually the ones with heavily-populated shorelines. Evaluations of the effects of these stressors on lakes should facilitate the identification of management priorities, including proactive and reactive interventions to mitigate stress. Here, understanding lakes as parts of waterscapes provides a more holistic perspective than narrower approaches focussing on single lakes. Specifically, to facilitate management, research could target the identification of specific lakes in a waterscape that may serve as havens of biodiversity and sentinels of ecological change for the entire waterscape. 


\subsection{A need to include a spatial dimension to the measurement of lake ecosystem resilience}

Much work on resilience in lakes has been inferred from temporal studies in individual lakes. However, such studies tell us little about the resilience of temporally highly dynamic systems that are part of a broader waterscape (Allen et al., 2016). Spatial resilience and spatial regimes (Sundström et al., 2017) are emergent concepts that can be useful to study broader waterscapes. This is exemplified by a recent avian study that could accurately reconstruct and predict how fast entire ecoregions move in the land scape in relation to environmental change (Roberts et al., 2019a). It would be interesting to assess how regime shifts in the terrestrial matrix affect a waterscape, i.e., whether or not waterscape regimes change in response to terrestrial regime changes.

\subsection{Comparative studies of lake ecosystem resilience}

Researchers need to assess the relevant spatio-temporal scales and ecological contexts (e.g., different lake types as defined above) objectively in comparative studies rather than being based on subjective definitions (e.g., defined by political boundaries, research-defined scales or limited ecological contexts). Surrogates of resilience have been developed, and an increasing amount of data is available that would allow for such comparisons (Nash et al., 2014; Angeler et al., 2016). Comparison of resilience-based assessments with traditional biodiversity studies should be made because these approaches may not show congruent results (Roberts et al., 2019b).

\subsection{A wrap-up with reality check}


There is an ongoing discussion about what we must or should do, but economic, political and practical research realities are an obstacle to the implementation of ecological theory to environmental management (Wuits, Driessen \& Van Rijswick, 2018). In other words, a lot of data are typically required for modelling (Verburg et al., 2016). We currently do not have enough data to examine most phenomena affecting the resilience of lake ecosystems, let alone entire waterscapes, although data sets that are suitable for resilience research are increasingly becoming available. Theoretical models alone may not be enough in making predictions of the changes in lake ecosystems in waterscapes in the Anthropocene. Thus, results from these models should also be recurrently validated with empirical field data. Ultimately, research across disciplinary fields is badly needed to address the challenges that the humanity faces in the Anthropocene (Angeler, Allen \& Carnaval, 2020), and in which lakes play an important role in providing ecosystem services.

\section{CONCLUSIONS}

Different types of lakes show different spatial organization, biological communities and ecosystem services that are spatially and temporally variable. This spatio-temporal dynamism dictates that managing lake biodiversity and ecosystem services cannot overlook feedback mechanisms. This also necessitates that lakes are considered in the regional context of metasystems, taking into account a lake's position in the landscape. Lakes high in the landscape may be relatively isolated, receiving less organisms and material from other lakes, while still being closely associated with the surrounding terrestrial ecosystem. This isolation means, however, that biological recovery after anthropogenic disturbances may last for a relatively long time because these head water lakes are not well connected to the pool of dispersing organisms. In contrast, lakes low in the landscape are well connected to other lakes and the 
drainage system, thereby receiving a constant flux of dispersing organisms to counter temporary extinctions of species. Such high connectivity also contributes to the higher potential capacity to recover from anthropogenic impacts. However, low-lying lakes are also the most affected by anthropogenic stressors, possibly resulting in long recovery times. Our main proposition is thus that understanding the biodiversity and ecosystem services lakes provide should be based on the waterscape approach because no lake is completely disconnected from surrounding terrestrial landscapes, other lakes or riverine systems, as was already pointed out by Forbes (1887). However, depending on the lake type, the relative roles of local and regional processes as well as anthropogenic stressors vary in determining biodiversity and ecosystem services, which should be taken into account in the adaptive management of lake ecosystems as parts of broader waterscapes in an increasingly humandominated world.

\section{FUNDING INFORMATION}

This work was funded by the Strategic Research Council of the Academy of Finland (Contract No. 312650 BlueAdapt). JA received funding from the Academy of Finland. Work of LMB has been supported by CNPq and FAPEG (304314/2014-5, 465610/2014-5). YC thanks the support from the National Natural Science Foundation of China (31670466). SH and PV were supported by the projects FRESHABITLIFE IP (LIFE14/IPE/FI/023) and the Strategic Research Council at the Academy of Finland (Grant no. 312559 IBC CARBON).

\section{CONFLICT OF INTEREST}


The authors have declared no conflicts of interest for this article.

\section{AUTHORS' CONTRIBUTIONS}

JH and DGA devised the main ideas and led the writing of this review. All authors contributed to the ideas throughout the paper.

\section{REFERENCES}

Adrian, R., O'Reilly, C.M., Zagarese, H., Baines, S.B., Hessen, D.O., Keller, W., Livingstone, D.M., Sommaruga, R., Straile, D., Van Donk, E., \& Weyhenmeyer, G.A. (2009) Lakes as sentinels of climate change. Limnology and Oceanography, 54, 2283-2297.

Alahuhta, J., Ala-Hulkko, T., Tukiainen, H., Purola, L., Akujärvi, A., Lampinen, R., \& Hjort, J. (2018) The role of geodiversity in providing ecosystem services at broad scales. Ecological Indicators, 91, 47-56.

Alahuhta, J., Rääpysjärvi, J., Hellsten, S., Kuoppala, M., \& Aroviita, J. (2015) Species sorting drives variation of boreal lake and river macrophyte communities. Community Ecology, 16, 76-85.

Alahuhta, J., \& Heino, J. (2013) Spatial extent, regional specificity and metacommunity structuring in lake macrophytes. Journal of Biogeography, 40, 1572-1582.

Ala-Hulkko, T., Kotavaara, O., Alahuhta, J., Helle, P., \& Hjort, J. (2016). Introducing accessibility analysis in mapping cultural ecosystem services. Ecological indicators, $66,416-427$. 
Allen, C.R., Angeler, D.G., Chaffin, B.C., Twidwell, D., \& Garmestani, A. (2019) Resilience reconciled. Nature Sustainability, 2, 898-900.

Allen, C.R., Angeler, D.G., Cumming, G.S., Folke, C., Twidwell, D., \& Uden, D.R. (2016) Quantifying spatial resilience. Journal of Applied Ecology, 53, 625-635.

Allen, C.R., Angeler, D.G., Garmestani, A.S., Gunderson, L.H., \& Holling, C.S. (2014) Panarchy: theory and application. Ecosystems, 17, 578-589.

Allan, J.D., Abell, R., Hogan, Z., Revenga, C., Taylor, B.W., Welcomme, R.L., \& Winemiller, K. (2005) Overfishing of inland waters. BioScience, 55, 1041-1051.

Anderson, E.P., Jenkins, C.N., Heilpern, S., Maldonado-Ocampo, J.A., Carvajal-Vallejos, F.M., Encalada, A.C., Rivadeneira, J.F., Hidalgo, M., Cañas, C.M., Ortega, H., Salgedo, N., Mald onado, M., \& Tedesco, P.A. (2018) Fragmentation of Andes-toAmazon connectivity by hydropower dams. Science Advances, 4, eaao1642.

Angeler, D. G. (2007) Resurrection ecology and global climate change research in freshwater ecosystems. Journal of the North American Benthological Society, 26, 12-22.

Angeler, D.G., Alvarez-Cobelas, M., Rojo, C., \& Sánchez-Carrillo, S. (2010) Phytoplankton community similarity in a semiarid floodplain under contrasting hydrological connectivity regimes. Ecological Research, 25, 513-520.

Angeler, D.G., Allen, C.R., \& Carnaval, A. (2020) Convergence science in the Anthropocene: Navigating the known and unknown. People and Nature, in press.

Angeler, D.G., Allen, C.R., \& Johnson, R.K. (2012) Insight on invasions and resilience derived from spatiotemporal discontinuities of biomass at local and regional scales. Ecology and Society, 17, 1239-1241. 
Angeler, D.G., Allen, C.R., Barichievy, C., Eason, T., Garmestani, A.S., Graham, N.A.J., ... Sund strom, S.M. (2016) Management applications of discontinuity theory. Journal of Applied Ecology, 53, 688-698.

Angeler, D.G., Baho, D.L., Allen, C.R., \& Johnson, R.K. (2015) Linking degradation status with ecosystem vulnerability to environmental change. Oecologia, 178, 899-913.

Angeler, D.G., Chaffin, B.C., Sund strom, S.M., Garmestani, A., Pope, K.L., Uden, D.R., ... Allen, C.R. (2020) Coerced regimes: managing artificial feedbacks to navigate the Anthropocene. Ecology and Society, 25, 4.

Angeler, D.G., \& Drakare, S. (2013) Tracing alpha, beta, and gamma diversity responses to environmental change in boreal lakes. Oecologia, 172, 1191.

Angeler, D.G., S. Drakare, S., Johnson, R.K., Köhler, S.J., \& Vrede, T. (2017) Managing ecosystems without prior knowledge: pathological outcomes of lake liming. Ecology and Society 22, 44 .

Angeler, D.G., \& Johnson, R.K. (2012) Temporal scales and patterns of invertebrate biodiversity dynamics in boreal lakes recovering from acidification. Ecological Applications, 22, 1172-1186.

Arantes, C.C., Fitzgerald, D.B., Hoeinghaus, D.J. \& Winemiller, K.O. (2019). Impacts of hydroelectric dams on fishes and fisheries in tropical rivers through the lens of functional traits. Current Opinion in Environmental Sustainability, 37, 28-40.

Arhonditsis, G.B., Neumann, A., Shimoda, Y., Kim, D-K, Dong, F., Onandia, G., Yang, C., Javed, A., Brady, M., Visha, A., Ni, F., \& Cheng, V. (2019) Castles built on sand or predictive limnology in action? Part A: Evaluation of an integrated modelling framework to guide adaptive management implementation in Lake Erie. Ecological Informatics, 53, 100968. 
Baho, D. L., S. Drakare, R. K. Johnson, C. R. Allen, \& D. G. Angeler. (2014) Similar resilience attributes in lakes with different management practices. PloS One, 9, e91881.

Baho, D. L., Allen, C.R., Garmestani, A.S., Fried-Petersen, H.B., Renes, S.E., Gunderson, L., \& Angeler, D.G. (2017) A quantitative framework for assessing ecological resilience. Ecology and Society, 22, 17.

Baxter, R.M., (1977) Environmental effects of dams and impoundments. Annual Review of Ecology and Systematics, 8, 255-283.

Birgé, H.E., Allen, C.R., Angeler, D.G., Bevans, R.A.\& Wall, D.H. (2016) Adaptive management for soil ecosystem services. Journal of Environmental Management, 183, $371-378$

Bangash, R.F., Passuello, A., Sanchez-Canales, M., Terrado, M., López, A., Elorza, F.J., ... Schuhmacher, M. (2013) Ecosystem services in Mediterranean river basin: climate change impact on water provisioning and erosion control. Science of the Total Environment, 458-460, 246-255.

Baron, J. S., Poff, N. L., Angermeier, P. L., Dahm, C. N., Gleick, P. H., Hairston, N. G., ... Steinman, A. D. (2002) Meeting ecological and societal needs for freshwater. Ecological Applications, 12, 1247-1260.

Barros, N., Cole, J.J., Tranvik, L.J., Prairie, Y.T., Bastviken, D., Huszar, V.L.M., ... Roland, F. (2011) Carbon emissions from hydroelectric reservoirs linked to reservoir age and latitude. Nature Geoscience, 4, 593-596. 
Bastviken, D., Cole, J., Pace, M., \& Tranvik, L. (2004) Methane emissions from lakes: dependence of lake characteristics, two regional assessments, and a global estimate. Global Biogeochemical Cycles, 18, GB4009

Bastviken, D., Tranvik, L.J., Downing, J.A., Crill, P.M. \& Enrich-Prast, A. (2011) Freshwater methane emissions off set the continental carbon sink. Science, 331, 50.

Berset, J-D., Brenneisen, R., \& Mathieu, C. (2010) Analysis of llicit and illicit drugs in waste, surface and lake water samples using large volume direct injection high performance liquid chromatography - Electrospray tandem mass spectrometry (HPLC-MS/MS). Chemosphere, 81, 859-866.

Bicudo, D.D.C., Fonseca, B.M., Bini, L.M., Crossetti, L.O., Bicudo, C.E.D.M., \& AraújoJesus, T. (2007) Undesirable side-effects of water hyacinth control in a shallow tropical reservoir. Freshwater Biology, 52, 120-1133.

Bilton D.T., Freeland J.R., \& Okamura B. (2001) Dispersal in freshwater invertebrates. Annual Review of Ecology and Systematics, 32, 159-181.

Blythe, J., Silver, J., Evans, L., Armitage, D., Bennett, N.J., Moore, M., Morrison, T.H., \& Brown, K. (2018) The dark side of transformation: Latent risks in contemporary sustainability discourse. Antipode, 50, 1206-1223.

Borrel, G., Jézéquel, D., Biderre-Petit, C., Morel-Desrosiers, N., Morel, J.P., Peyret, P., ... Lehours, A.C. (2011) Production and consumption of methane in lake ecosystems. Research in Microbiology, 162, 832-847.

Bozelli, R.L., Thomaz, S.M., Padial, A.A., Lopes, P.M., \& Bini, L.M. (2015) Flood s decrease zooplankton beta diversity and environmental heterogeneity in an Amazonian floodplain system. Hydrobiologia, 753, 233-241. 
Brilha, J., Gray, M., Pereira, D.I., \& Pereira, P., (2018). Geodiversity: An integrative review as a contribution to the sustainable management of the whole of nature. Environmental Science \& Policy, 86, 19-28.

Browne M.A., Dissanayake, A., Galloway T.S., Lowe D.M., \& Thompson R.C. (2008) Ingested microscopic plastic translocates to the circulatory system of the mussel, Mytilus edulis (L.). Environmental Science \& Technology, 42, 5026-5031.

Buffam, I., Turner, M.G., Desai, A.R., Hanson, P.C., Rusak, J.A., Lottig, N.R., Stanley, E.H., \& Carpenter, S.R. (2011) Integrating aquatic and terrestrial components to construct a complete carbon budget for a north temperate lake district. Global Change Biology, $17,1193-1211$.

Butler, J.R.A., Radford, A., Riddington, G., \& Laughton, R. (2009). Evaluating an ecosystem service provided by Atlantic salmon, sea trout and other fish species in the River Spey, Scotland: the economic impact of recreational rod fisheries. Fisheries Research, 96, 259-266.

Cai, Y., Xu, H., Vilmi, A., Tolonen, K.T., Tang, X., Qin, B., Gong, Z., \& Heino, J. (2017). Relative roles of spatial processes, natural factors and anthropogenic stressors in structuring a lake macroinvertebrate metacommunity. Science of the Total Environment, 601, 1702-1711.

Caller, T.A., Doolin, J.W., Haney, J.F., West, K.G., Farrar, H.E., Ball, A. ... Stommel, E.W. (2009) A cluster of amyotrophic lateral sclerosis in New Hampshire: a possible role for toxic cyanobacteria blooms. Amyotrophic Lateral Sclerosis, 10, 101-108.

Cambray, J.A. (2003) Impact on indigenous species biodiversity caused by the globalisation of alien recreational freshwater fisheries. Hydrobiologia, 500, 217-230. 
Cardinale, B. J., Duffy, J.E.. Gonzalez, A., Hooper, D.U., Perrings, C. Venail, P., ... Naeem, S. (2012). Biodiversity loss and its impact on humanity. Nature, 486, 59-67.

Carpenter, S.R. (2003). Regime Shifts in Lake Ecosystems: Pattern and Variation. Excellence in Ecology, 15, 1-195.

Carpenter, S.R. (2005) Eutrophication of aquatic ecosystems: bi-stability and soil phosphorus. Proceedings of the National Academy of Sciences 102, 10002-10005.

Carpenter, S.R., Stanley, E.H., \& Vander Zanden, M.J. (2011) State of the World's freshwater ecosystems: physical, chemical, and biological changes. Annual Review of Environment and Resources 36, 75-99.

Castillo-Escrivà, A., Valls, L., Rochera, C., Camacho, A., \& Mesquita-Joanes, F. (2016) Spatial and environmental analysis of an ostracod metacommunity from endorheic lakes. Aquatic Sciences, 78, 707-716.

Clair, T. A., \& Hindar, A. (2005) Liming for the mitigation of acid rain effects in freshwaters: a review of recent results. Environmental Reviews, 13, 91-128.

Cole, J.J., Prairie, Y.T., Caraco, N.F., McDowell, W.H., Tranvik, L.J., Striegl, R.G.... Melack, J. (2007) Plumbing the global carbon cycle: integrating inland waters into the terrestrial carbon budget. Ecosystems, 10, 171-184.

Coll, M., Libralato, S., Tudela, S., Palomera, I., \& Pranovi, F. (2008) Ecosystem overfishing in the ocean. PLoS ONE, 3, e3881.

Comte, L., Buisson, L., Daufresne, M., \& Grenouillet, G. (2013) Climate-ind uced changes in the distribution of freshwater fish: observed and predicted trends. Freshwater Biology, 58, 625-639. 
Costanza, R., de Groot, R.,Sutton, P., van der Ploeg, S., Anderson, S.J., Kubiszewski, I., ... Turner, R.K. (2014) Changes in the global value of ecosystem services. Global Environmental Change 26, 152-158.

Cottenie, K., Michels, E., Nuytten, N., \& De Meester, L. (2004) Zooplankton metacommunity structure: regional vs. local processes in highly interconnected ponds. Ecology, 84, 991-1000.

Cowx, I.G., Arlinghaus, R., \& Cooke, S.J. (2010) Harmonizing recreational fisheries and conservation objectives for aquatic biodiversity in inland waters. Journal of Fish Biology, 76, 2194-2215.

Crook, D.A., Lowe, W.H., Allend orf, F.W., Erös, T., Finn, D.S., Gillanders, B.M., Hadwen, W.L., Harrod, C., Hermoso, V., Jennings, S., Kilada, R.W., Nagelkerken, I., Hansen, M.M., Page, T.J., Riginos, C., Fry, B., \& Hughes, J.M. (2015) Human effects on ecological connectivity in aquatic ecosystems: integrating scientific approaches to support management and mitigation. Science of the Total Environment, 534, 52-64.

Cumming, G.S. (2011) Spatial Resilience in Social-Ecological Systems. Springer.

Datry, T., Bonada, N. \& Heino, J. (2016) Towards understanding the organisation of metacommunities in highly dynamic ecological systems. Oikos, 125, 149-159.

De Bie, T., De Meester, L., Brendonck, L., Martens, K., Goddeeris, B., Ercken, D., ... Van Wichelen, J. (2012) Body size and dispersal mode as key traits determining metacommunity structure of aquatic organisms. Ecology Letters, 15, 740-747.

de Groot, R., Brander, L., van der Ploeg, S., Costanza, R., Bernard, F., Braat, L., ... van Beukering, P. (2012). Global estimate of the value of ecosystems and their services in monetary units. Ecosystem Services, 1, 50-61. 
Delpla, I. Jung, A.V. Baures, E., Clement, M., \& Thomas, O. (2009) Impacts of climate change on surface water quality in relation to drinking water production. Environment International, 35, 1225-1233.

Diekmann, M., Brämick, U., Lemcke, R., \& Mehner, T. (2005) Habitat-specific fishing revealed distinct indicator species in German lowland lake fish communities. Journal of Applied Ecology, 42, 901-909.

Dodds, W.K. (2003) The role of periphyton in phosphorus retention in shallow freshwater aquatic ecosystems. Journal of Phycology, 39, 840-849.

Dodds, W.K., Bouska, W.W., Eitzmann, J.L., Pilger, T.J., Pitts, K.L., Riley, A.J., ... Thornbrugh, D.J. (2009) Eutrophication of U.S. freshwaters: analysis of potential economic damages. Environmental Science \& Technology, 43, 12-19.

Donnelly, C., Greuell, W., Andersson, J., Gerten, D., Pisacane, G., Roudier, P. \& Ludwig, F. (2017). Impacts of climate change on European hydrology at 1.5, 2 and 3 degrees mean global warming above preindustrial level. Climatic Change, 143, 13-26.

Downing, J.A., Prairie, Y.T., Cole, J.J., Duarte, C.M., Tranvik, L.J., Striegl, R.G., ... Middelburg, J.J. (2006). The global abundance and size distribution of lakes, pond s and impoundments. Limnology and Oceanography, 51, 2388-2397.

Downing, J.A., Cole, J.J., Middelburg, J.J., Striegl, R.G., Duarte, C.M., Kortelainen, P., Prairie, Y.T., \& Laube, K.A. (2008). Sediment organic carbon burial in agriculturally eutrophic impoundments over the last century. Global Biogeochemical Cycles, 22, GB1018. 
Duarte, C.M., Conley, D.J., Carstensen, J., \& Sánchez-Camacho, M. (2009). Return to Neverland: shifting baselines affect eutrophication restoration targets. Estuaries and Coasts, 32, 29-36.

Dudgeon, D., Arthington, A.H., Gessner, M.O., Kawabata, Z., Knowler, D., Lévêque, C., ... Sullivan, C.A. (2006). Freshwater biodiversity: importance, threats, status and conservation challenges. Biological Reviews, 81, 163-182.

Egoh, B., Drakou, E.G., Dunbar, M.B., Maes, J., \& Willemen, L. (2012) Indicators for mapping ecosystem services: a review. Report EUR 25456 EN. Publications office of the European Union, Luxembourg.

Einola, E., Rantakari, M., Kankaala, P., Kortelainen, P., Ojala, A., Pajunen, H., Mäkelä, S., \& Arvola, L. (2011) Carbon pools and fluxes in a chain of five boreal lakes: A dry and wet year comparison, Journal of Geophysical Research, 116, G03009.

EU (2011) EU intervention in inland fisheries. EU wide report.

FAO (2018). The state of world fisheries and aquaculture. FAO, Rome.

Fernandes, I. M., Henriques-Silva, R., Penha, J., Zuanon, J., \& Peres-Neto, P. R. (2014) Spatiotemporal dynamics in a seasonal metacommunity structure is predictable: the case of flood plain-fish communities. Ecography, 37, 464-475.

Ferrão-Filho, A. da S., \& Kozlowsky-Suzuki, B. (2011) Cyanotoxins: Bioaccumulation and Effects on Aquatic Animals. Marine Drugs, 9, 2729-2772.

Ficke, A.D., Myrick, C.A., \& Hansen L.J. (2007) Potential impacts of global climate change on freshwater fisheries. Reviews in Fish Biology and Fisheries, 17, 581-613. 
Fisher, E.K., Paglialonga, L., Czech, E., \& Tamminga, M. (2016). Microplastic pollution in lakes and lake shoreline sediments - A case study on Lake Bolsena and Lake Chiusi (central Italy). Environmental Pollution, 213, 648-657.

Forbes, S.A. (1887) The Lake as a Microcosm. Bulletin of the Scientific Association of Peoria, Illinois, 77-87. Reprinted in Illinois Natural History Survey Bulletin, 15, 537550.

Fried-Petersen, H.B., Ayala-Ajoy, Y., Futter, M.N., \& Angeler, D.G. (2020) Long-term invertebrate community stability in changing boreal lakes. Global Change Biology, in press.

Grennfelt, P., Engleryd, A., Forsius, M., Hov, O., Rodhe, H., \& Cowling, E. (2020) Acid rain and air pollution: 50 years of progress in environmental science and policy. Ambio, $49,849-864$.

Guo W., F.I. Hai, Liang, S., Luo, Y., Nghiem, L.D., Ngo, H.H., Wang, X.C. \& Zhang, J. (2014). A review on the occurrence of micropollutants in the aquatic environment and their fate and removal during wastewater treatment. Science of the Total Environment, 473-474, 619- 641 .

Gulati, R. D., L. M. D. Pires, \& E. Van Donk. (2008) Lake restoration studies: failures, bottlenecks and prospects of new ecotechnological measures. Limnologica, 38, 233247.

Harrison, P.A., Berry, P.M., Simpson, G., Haslett, J.R., Blicharska, M., Bucur, M., ... Turkelboom, F. (2014) Linkages between biodiversity attributes and ecosystem services: a systematic review. Ecosystem Services, 9, 191-203.

Heino, J. (2013b) Does dispersal ability affect the relative importance of environmental control and spatial structuring of littoral macroinvertebrate communities? Oecologia, $171,971-980$. 
Heino, J., Melo, A.S., Siqueira, T., Soininen, J., Valanko, S., \& Bini, L.M. (2015)

Metacommunity organisation, spatial extent and dispersal in aquatic systems: patterns, processes and prospects. Freshwater Biology, 60, 845-869.

Heino, J., Soininen, J., Alahuhta, J., Lappalainen, J., \& Virtanen, R. (2017) Metacommunity ecology meets biogeography: Effects of geographical region, spatial dynamics and environmental filtering on community structure in aquatic organisms. Oecologia, 183, $121-137$.

Heino, J., Virkkala, R., \& Toivonen, H. (2009) Climate change and freshwater biodiversity: detected patterns, future trends and adaptations in northern regions. Biological Reviews, 84, 39-54.

Hellsten, S., Marttunen, M., Palomäki, R., Riihimäki, J., \& Alasaarela, E. (1996) Towards an ecologically based regulation practice in Finnish hydroelectric lakes. River Research and Applications, 12, 535-545.

Henriksson, L., \& Brodin, Y.N. (1995) Liming of Acidified Surface Waters: A Swedish Synthesis. Springer, Berlin.

Herdendorf, C. E. (1982) Large lakes of the world. Journal of Great Lakes Research, 8, 379412.

Holling, C.S. (1973) Resilience and stability of ecological systems. Annual Review of Ecology and Systematics, 4, 1-23.

Holling, C. S., \& Meffe, G.K. (1996) Command and control and the pathology of natural resource management. Conservation Biology, 10, 328-337.

Hubbell, S.J. (2001) The Unified Neutral Theory of Biodiversity and Biogeography. Monographs in Population Biology 32. Princeton University Press, Princeton. 
Isbell, F., Gonzalez, A., Loreau, M., Cowles, J., Díaz, S., Hector, A., ... Larigauderie, A. (2017) Linking the influence and dependence of people on biodiversity across scales. Nature, 546, 65-72.

Iversen, L.L., Winkel, A., Baastrup-Spohr, L., Hinke, A.B., Alahuhta, J., Baattrup- Pedersen, A., ... Pedersen, O. (2019) Catchment properties and the photosynthetic trait composition of freshwater plant communities. Science, 366, 878-881.

Januchowski-Hartley, S.R., McIntyre, P.B., Diebel, M., Doran, B.J., Infante, D.M., Joseph, C., \& Allan, J.D. (2013) Restoring aquatic ecosystem connectivity requires expanding inventories of both dams and road crossings. Frontiers in Ecology and Environment, $11,211-217$.

Jia, P. Q., Zhang, W. B., \& Liu, Q. G. (2013). Lake fisheries in China: challenges and opportunities. Fisheries Research, 140, 66-72.

Johnson, L.E., \& Padilla, D.K. (1996) Geographic spread of exotic species: ecological lessons and opportunities from the invasion of the zebra mussel Dreissena polymorpha. Biological Conservation, 78, 23-33.

Johnson, L.E., Ricciardi, A., \& Carlton, J.T. (2001) Overland dispersal of aquatic invasive species: a risk assessment of transient recreational boating. Ecological Applications, 11, 1789-1799.

Junk, W.J., Bayley, P.B., \& Sparks, R.E. (1989) The flood pulse concept in river-floodplain systems. Canadian Special Publication of Fisheries and Aquatic Sciences, 106, 110127. 
Kelly, N.E., Wantola, K., Weisz, E., \& Yan, N.D. (2013) Recreation boats as a vector of secondary spread for aquatic invasive species and native crustacean zooplankton. Biological Invasions, 15, 509-519.

Kemenes, A., Forsberg, B.R., \& Melack, J.M. (2007) Methane release below a tropical hydroelectric dam. Geophysical Research Letters, 34, L12809.

Kling, G.W., Kipphut, G.W., Miller, M.M., \& O’Briens, J. (2000) Integration of lakes and streams in a landscape perspective: the importance of material processing on spatial patterns and temporal coherence. Freshwater Biology, 43, 477-497.

Kneitel, J. M., \& Miller, T.E. (2003) Dispersal rates affect community composition in metacommunities of Sarracenia purpurea inquilines. American Naturalist, 162, 165171.

Kok, M.T., K. Kok, K., Peterson,G.D., Hill, R., Agard, J., \& Carpenter, S.R. (2017) Biodiversity and ecosystem services require IPBES to take novel approach to scenarios. Sustainability Science, 12, 177-181.

Kortelainen, P., Mattsson, T., Finér, L., Ahtiainen, M., Saukkonen, S., \& Sallantaus, T. (2006) Controls on the export of C, N, P and Fe from undisturbed boreal catchments, Finland. Aquatic Sciences, 68, 453-468.

Kortelainen, P., Pajunen, H., Rantakari, M., \& Saarnisto, M. (2004) A large carbon pool and small sink in boreal Holocene lake sediments. Global Change Biology, 10, 1648-1653.

Kortelainen, P., Rantakari, M., Huttunen, J.T., Mattsson, T., Alm, J., Juutinen, S., Larmola, T., Silvola, J., \& Martikainen, P.J. (2006) Sediment respiration and lake trophic state are important predictors of large $\mathrm{CO}_{2}$ evasion from small boreal lakes. Global Change Biology, 12, 1554-1567. 
Kratz, T.K., Webster, K.E., BowSeries, C.J., Magnuson, J.J., \& Benson, B.J. (1997) The influence of landscape position on lakes in northern Wisconsin. Freshwater Biology, 37, 209-217.

Le Quéré, C., Moriarty, R., Andrew, R.M., Peters, G.P., Ciais, P, Friedlingstein, P., ... Zeng, N. (2015). Global carbon budget 2014. Earth System Science Data, 7, 47-85.

Lees, A.C., Peres, C.A., Fearnside, P.M., Schneider, M., \& Zuanon, J.A.S. (2016) Hydropower and the future of Amazonian biodiversity. Biodiversity and Conservation, 25, 451-466.

Leibold, M. A. et al., 2004. The metacommunity concept: a framework for multi-scale community ecology. Ecology Letters, 7, 601-613.

Lewis, D.B., \& Magnuson, J.J. (2000) Landscape spatial patterns in freshwater snail assemblages across Northern Highland catchments. Freshwater Biology, 43, 409-420.

Loreau, M., Mouquet, N., \& Holt, R. D. (2003) Meta-ecosystems: a theoretical framework for a spatial ecosystem ecology. Ecology Letters, 6, 673-679.

Mace, G.M., Norris, K., \& Fitter, A.H. (2012) Biodiversity and ecosystem services: a multilayered relationship. Trends in Ecology and Evolution, 27, 19-26.

Mackintosh, C., Griggs, G., \& Tate, R. (2019). Understanding the growth in outdoor recreation participation: an opportunity for sport development in the United Kingdom. Managing Sport and Leisure, in press. DOI: 10.1080/23750472.2019.1595093.

Magnuson, J. J., Tonn, W. M., Banerjee, A., Toivonen, J., Sanchez, O., \& Rask, M. (1998). Isolation vs extinction in the assembly of fishes in small lakes. Ecology, 79, 29412956. 
Mattsson, T., Kortelainen, P., \& Räike, A. (2005) Export of DOM from boreal catchments: Impacts of land use cover and climate. Biogeochemistry, 76, 373-394.

McCrackin, M.L., Jones, H.P., Jones, P.C., \& Moreno-Mateos, D., (2017). Recovery of lakes and coastal marine ecosystems from eutrophication: A global meta-analysis. Limnology and Oceanography, 62, 507-518.

Maloufi, S., Catherine, A., Mouillot, D., Louvard, C., Couté, A., Bernard, C. \& Troussellier, M. (2016) Environmental heterogeneity among lakes promotes hyper $\beta$-diversity across phytoplankton communities. Freshwater Biology, 61, 633-645.

Martiny, J. B., et al. 2006. Microbial biogeography: putting microorganisms on the map. Nature Reviews in Microbiology, 4, 102-112.

Mason, S.A., Kammin, L., Eriksen, M., Aleid, G., Wilson, S., Box, C., ... Riley, A. (2016). Pelagic plastic pollution within the surface waters of Lake Michigan, USA.

McCluney, K. E., Poff, N. L., Palmer, M. A., Thorp, J. H., Poole, G. C., Williams, B. S., Williams, M. R., \& Baron, J. S. (2014) Riverine macrosystems ecology: sensitivity, resistance, and resilience of whole river basins with human alterations. Frontiers in Ecology and the Environment, 12, 48-58.

McIntyre, P.B., Liermann, C.A.R., \& Revenga, C. (2016) Linking freshwater fishery management to global food security and biodiversity conservation. Proceedings of the National Academy of Sciences, 113, 12880-12885.

Melstrom, R.T., \& Lupi, F. (2013) Valuing recreational fishing in Great Lakes. North American Journal of Fisheries Management, 33, 1184-1193. 
Metcalfe C.D., Miao, X-S., Koenig, B.G., \& Struger, J. (2003). Distribution of acidic and neutral drugs in surface waters near sewage treatment plants in the lower Great Lakes, Canada. Environmental Toxicology and Chemistry, 22, 2881-2889.

Millennium Ecosystem Assessment (2005) Ecosystems and human well-being: wetlands and water. Synthesis. World Resources Institute, Washington, DC.

Milly, P.C., Betancourt, J., Falkenmark, M., Hirsch, R.M., Kundzewicz, Z.W., Lettenmaier, D.P., \& Stouffer, R.J. (2008) Stationarity is dead: Whither water management? Science, 319, 573-574.

Mitchell, M.G.E., Bennett, E.M., \& Gonzalez, A. (2013). Linking landscape connectivity and ecosystem service provision: Current knowledge and research gaps. Ecosystems, 16, 894-908.

Mouquet N., \& Loreau, M. (2003) Community patterns in source-sink metacommunities. American Naturalist, 162, 544-557.

Murcia, C., Aronson, J., Kattan, G. H., Moreno-Mateos, D., Dixon, K., \& Simberloff, D. (2014) A critique of the 'novel ecosystem' concept. Trends in Ecology and Evolution, 29, 548-553.

Nash, K.L, Allen, C.R., Angeler, D.G., Barichievy, C., Eason, T., Garmestani, A.S., ... Sundstrom, S.M. (2014) Discontinuities, cross-scale patterns and the organization of ecosystems. Ecology, 95, 654-667.

Nelson, E., Mendoza, G., Regetz, J., Polasky, S., Tallis, H., Cameron, D.R., ... Shaw, M.R. (2009) Modeling multiple ecosystem services, biodiversity conservation, commodity production, and tradeoffs at landscape scales. Frontiers in Ecology and the Environment, 7, 4-11. 
Olden, J., Jackson, D. A. \& Peres-Neto, P. R. (2001). Spatial isolation and fish communities in drainage lakes. Oecologia, 127, 572-585.

O’Reilly, C.M., Alin, S.R., Plisnier, P.D., Cohen, A.S., \& McKee, B.A. (2003) Climate change decreases aquatic ecosystem productivity of Lake Tanganyika, Africa. Nature, $424,766-768$.

Oswald, K., Milucka, J., Brand, A., Hach, P., Littmann, S., Wehrli, B., ... Schubert, C.J. (2016) Aerobic gammaproteobacterial methanotrophs mitigate methane from oxic and anoxic lake waters. Limnology and Oceanography, 61, S101-S118.

Padial, A. A., Ceschin, F., Declerck, S. A. J., De Meester, L., Bonecker, C. C., Lansac-Tôha, F. A., ... Bini, L. M. (2014) Dispersal Ability Determines the Role of Environmental, Spatial and Temporal Drivers of Metacommunity Structure. PLoS One, 9, e111227.

Pauly, D., (1995). Anecdotes and the shifting baseline syndrome of fisheries. Trends in Ecology \& Evolution, 10, 430.

Pauly, D. \& Zeller, D. (2016) Catch reconstructions reveal that global marine fisheries catches are higher than reported and declining. Nature Communications, 7, 10244.

Petsch, D.C., Pinha, G., \& Takeda, A.M. (2016) Dispersal mode and flooding regime as drivers of benthic metacommunity structure in a Neotropical floodplain. Hydrobiologia, in press.

Petticrew, E.L., \& Kalff, J. (1992) Water flow and clay retention in submerged macrophyte beds. Canadian Journal of Fisheries and Aquatic Sciences, 49, 2483-2489.

Pope, K.L., Allen, C.R., \& Angeler, D.G. (2014) Fishing for resilience. Transactions of the American Fisheries Society, 43, 467-478. 
Qin, B., Zhu, G., Gao, G., Zhang, Y., Li, W., Paerl, H.W. \& Carmichael, W.W. (2010). A drinking water crisis in Lake Taihu, China: linkage to climate variability and lake management. Environmental Management, 45, 105-112.

Rahel, F.J. (2007) Biogeographic barriers, connectivity and homogenization of freshwater faunas: it's a small world after all. Freshwater Biology, 52, 696-710.

Reconomics Plus (2017) The economic, health and social value of outdoor recreation. Manchester Metropolitan University. 25 pp.

Reid A.J., Carlson A.K., Creed I.F., Eliason E.J., Gell P.A., Johnson P.T.J., ... Cooke S.J. (2019). Emerging threats and persistent conservation challenges for freshwater biodiversity. Biological Reviews, 94, 849-873.

Riera, J.L., Magnuson, J.J., Kratz, T.K., \& Webster, K.E. (2000) A geomorphic template for the analysis of lake districts applied to the Northern Highland Lake District, Wisconsin, U.S.A. Freshwater Biology, 43, 301-318.

Rist, L., Felton, A., Nyström, M., Troell, M., Sponseller, R.A., Bengtsson, J., Österblom, H., Lindborg, R., Tidåker, P., Angeler, D.G., Milestad, R., \& Moen, J. (2014) Applying resilience thinking to production ecosystems. Ecosphere, 5, 73.

Roberts, C.P., Allen C.R., Angeler, D.G. \& Twidwell, D. (2019a) Shifting spatial regimes in a changing climate. Nature Climate Change, 9, 562-566.

Roberts, C.P., Twidwell, D., Angeler, D.G. \& Allen C.R. (2019b) How do ecological resilience metrics relate to community stability and collapse? Ecological Indicators, 107: 105552 
Sandoy, S., \& Romunstad, A.J. (1995) Liming of acidified lakes and rivers in Norway. An attempt to preserve and restore biological diversity in the acidified regions. Water, Air, and Soil Pollution, 85, 997-1002.

Scheffer, M., Hosper, S.H., Meijer, M.L., Moss, B. \& Jeppesen, E. (1993) Alternative equilibria in shallow lakes. Trends in Ecology \& Evolution 8,275-279.

Schindler, D. W. (1988) Effects of acid rain on freshwater ecosystems. Science, 239, 149157.

Schrodt, F., Bailey, J.J., Kissling, W.D., Rijsdijk, K.F., Seijmonsbergen, A.C., van Ree, D., ... Field, R. (2019). To advance sustainable stew ardship, we must document not only biodiversity but geodiversity. Proceedings of the National Academy of Sciences, 116, $16155-16158$.

Schubert, C.J., Lucas, F.S, Durisch-Kaiser, E., Stierli, R., Diem, T., Scheidegger, O., ... Müller, B. 2010. Oxidation and emissions of methane in a monomictic lake (Rotsee, Switzerland). Aquatic Sciences, 72, 455-466.

Scharnweber, K., Vanni M.J., Hilt S., Syväranta J., \& Mehner T. (2014) Boomerang ecosystem fluxes: organic carbon inputs from land to lakes are returned to terrestrial food webs via aquatic insects. Oikos, 123, 1439-1448.

Setälä, O., Fleming-Lehtinen, V., \& Lehtiniemi, M. (2014) Ingestion and transfer of microplastics in the planktonic food web. Environmental Pollution, 185, 77-83.

Simões, N. R., Dias, J.D., Leal, C.M., Braghin, L.S.M., Lansac-Tôha, F.A. \& Bonecker, C.C. (2013) Floods control the influence of environmental gradients on the diversity of zooplankton communities in a Neotropical floodplain. Aquatic Sciences, 75, 607-617. 
Simonit, S., \& Perrings, C. (2011) Sustainability and the value of the 'regulating' services: wetlands and water quality in Lake Victoria. Ecological Economics, 70, 1189-1199.

Smol, J.P. (2019) Under the radar: long-term perspectives on ecological changes in lakes. Proceedings of the Royal Society B, 286.

Soininen, J., Korhonen, J.J., Karhu, J., \& Vetterli, A. (2011) Disentangling the spatial patterns in community composition of prokaryotic and eukaryotic lake plankton. Limnology and Oceanography, 56, 508-520.

Soininen, J., Bartels, P., Heino, J., Luoto, M., \& Hillebrand, H. (2015) Toward more integrated ecosystem research in aquatic and terrestrial environments. BioScience, 65, 174-182.

Soranno, P.A., Cheruvelil, K.S., Webster, K.E., Bremigan, M.T., Wagner, T., \& Stow, C.A. 2010. Using land scape limnology to classify freshwater ecosystems for multiecosystem management and conservation. BioScience, 60, 440-454.

Soranno, P.A, Webster, K.E., Riera, J.L., Kratz, T.K., Baron, J.S., Bukaveckas, P., Kling, G.W., White, D., Caine, N., Lathrop R.C., \& Leavitt, P.R. (1999) Spatial variation among lakes within landscapes: Ecological organization along lake chains. Ecosystems, 2, 395-410.

Spanbauer, T., Allen, C.R., Angeler, D.G., Eason, T., Fritz, S.C., Garmestani, A.S., ... Stone, J.R. (2014) Prolonged instability prior to a regime shift. PLoS ONE, 9, e108936.

Sport and Recreation Alliance (2017) Reconomics Plus. The economic, health and social value of outdoor recreation. Mancester Metropolitan University. 25 pp. 
Steffen, W., Persson, Å., Deutsch L., Zalasiewicz, J., Williams, M., Richardson, K., ... Svedin, U. (2011) The Anthropocene: from global change to planetary steward ship. Ambio, 40, 739-761.

Soga, M. \& Gaston, K.J., (2018). Shifting baseline syndrome: causes, consequences, and implications. Frontiers in Ecology and the Environment, 16, 222-230.

Søndergaard, M., Jensen, J.P., \& Jeppesen, E. (2001) Retention and internal loading of phosphorus in shallow, eutrophic lakes. The Scientific World, 1, 427-442.

Suding, K. N., Gross, K.L., \& Houseman, G.R. (2004) Alternative states and positive feedbacks in restoration ecology. Trends in Ecology \& Evolution, 19, 46-53.

Sund strom, S.M., Eason, T., Nelson, R.J., Angeler, D.G., Allen, C.R., Barichievy, C., ... Stow, C.A. (2017) Detecting spatial regimes in ecosystems. Ecology Letters, 20, 1932

Thomaz, S. M., Bini, L.M., \& Bozelli, R.L. (2007) Floods increase similarity among aquatic habitats in river-flood plain systems. Hydrobiologia, 579, 1-13.

Tockner, K., Pennetzdorfer, D., Reiner, N., Schiemer, F., \& Ward, J.V. (1999) Hydrological connectivity, and the exchange of organic matter and nutrients in a dynamic riverfloodplain system (Danube, Austria). Freshwater Biology, 41, 521-535.

Toivanen, M., Hjort, J., Heino, J., Tukiainen, H., Aroviita, J., \& Alahuhta, J. (2019) Is catchment geodiversity a useful surrogate of aquatic plant species richness? Journal of Biogeography, 46, 1711-1722.

Tolonen, K.T., Hämäläinen, H., Lensu, A., Meriläinen, J.J., Palomäki, A., \& Karjalainen, J. (2014) The relevance of ecological status to ecosystem functions and services in a large boreal lake. Journal of Applied Ecology, 51, 560-571. 
Tolonen, K.T., Vilmi, A., Karjalainen, S.M., Hellsten, S., Sutela, T., \& Heino, J. (2017) Ignoring spatial effects results in inadequate models for variation in littoral macroinvertebrate diversity. Oikos, 126, 852-862.

Tonn, W. M., \& Magnuson, J. J. (1982). Patterns in the species composition and richness of fish assemblages in Northern Wisconsin lakes. Ecology, 63,1149-1166.

Tranvik, L.J., Downing, J.A., Cotner, J.B., Loiselle, S.A., Striegl, R.G., Ballatore, T.J., ... Weyhenmeyer, G.A. 2009. Lakes and reservoirs as regulators of carbon cycling and climate. Limnology and Oceanography, 54, 2298-2314.

Truchy, A., Angeler, D.G., Sponseller, R.A., Johnson, R.K., \& McKie, B.G. (2015) Linking Biodiversity, ecosystem functioning and services, and ecological resilience: towards an integrative framework for improved management. Advances in Ecological Research, 53, 55-96.

Van der Ploeg, S., \& de Groot, R.S. (2010) The TEEB valuation database - a searchable database of 1310 estimates of monetary values of ecosystem services. Foundation for Sustainable Development, Wageningen, the Netherlands.

van Ree, C.C.D.F., Beukering, P.J.H., \& Boekestijna, J. (2017). Geosystem services: A hidden link in ecosystem management. Ecosystem Services, 26, 58-69.

Verburg, P.H., Dearing, J.A., Dyke, J.G., van der Leeuw, S., Seitzinger, S., Steffen, W., \& Syvitski, J. (2016) Methods and approaches to modelling the Anthropocene. Global Environmental Change, 39, 328-340.

Vilbaste, S., Järvalt, A., Kalpus, K., Nõges, T., Pall, P., Piirsoo, K., ... Nõges, P. (2016) Ecosystem services of Lake Võrtsjärv under multiple stress: a case study. Hyd robiologia, 780, 145-159. 
Vilmi, A., Karjalainen, S.M., Hellsten, S. \& Heino, J. (2016) Bioassessment in a metacommunity context: are diatom communities structured solely by species sorting? Ecological Indicators, 62, 86-94.

Vilmi, A., Karjalainen, S.M., \& Heino, J. (2017). Ecological uniqueness of stream and lake diatom communities shows different macroecological patterns. Diversity and Distributions, 23, 1042-1053.

Vörösmarty, V.J., McIntyre, P.B., Gessner, M.O., Dudgeon, D., Prusevich, A., Green, P., ... Davies, P.M. (2010) Global threats to human water security and river biodiversity. Nature, 467, 555-561.

Wang, R., Dearing, J.A., Langdon, P.G., Zhang, E., Yang, X., Dakos, V., \& Scheffer, M. (2012) Flickering provides early warning signals of a critical transition to a eutrophic lake state. Nature, 492, 419-422.

Wang, R., Dearing, J.A., Doncaster, C.P., Yang, X., Zhang, E., Langdon, P.G., Yang, H., Dong, X., Hu, Z., Xu, M., Zhao, Y., \& Shen J. (2019) Network parameters quantify loss of assemblage structure in human-impacted lake ecosystems. Global Change Biology, 25, 3871-3882.

Ward, J.V., Tockner, K., \& Schiemer, F. (1999) Biodiversity of floodplain river ecosystems: ecotones and connectivity. River Research and Applications, 15, 125-139.

Waters, C.N., et al. (2016) The Anthropocene is functionally and stratigraphically distinct from the Holocene. Science, 351, 137.

Welcomme, R.L., Cowx, I.G., Coates, D., Béné, C., Funge-Smith, S., Halls, A., \& Lorenzen, K. (2010) Inland capture fisheries. Philosophical Transaction of the Royal Society B, $365,2881-2896$. 
Whitehead, P.G., Wilby, R.L., Battarbee, R.W., Kernan, M., \& Wade, A.J. (2009) A review of the potential impacts of climate change on surface water quality. Hydrological Sciences Journal, 54, 101-123.

Wieser, C. (2019) Fighting the disappearance of Balkan rivers. The Ecological Citizen, 2, $131-135$.

Wiggins, G. B. et al. (1980) Evolutionary and ecological strategies of animals in annual temporary pools. Arch. Hydrobiologie Supplement, 58, 97-206.

Williams, P., Whitfield, M., Biggs, J., Bray, S., Fox, G., Nicolet, P., \& Sear, D. (2004) Comparative biodiversity of rivers, streams, ditches and ponds in an agricultural landscape in Southern England. Biological Conservation, 115, 329-341.

Williamson, C.E., Saros, J.E., Vincent, W.F., \& Smol, J.P. (2009) Lakes and reservoirs as sentinels, integrators and regulators of climate change. Limnology and Oceanography, $54,2273-2282$.

Winegardner, A. K. et al., (2012) The terminology of metacommunity ecology. Trends in Ecology and Evolution, 27, 253-254.

Winfield, I.J. (2016) Recreational fisheries in the UK: natural capital, ecosystem services, threats, and management. Fisheries Science, 82, 203-212.

Wu, T., et al. (2015) The influence of changes in wind patterns on the areal extension of surface cyanobacterial blooms in a large shallow lake in China. Science of the Total Environment, 518-519, 24-30.

Wuijts, S., Driessen, P.P.J., \& Van Rijswick, H.F.M.W. (2018) Towards more effective water quality governance: A review of social-economic, legal and ecological Perspectives and Their Interactions. Sustainability, 10, 1-19. 
Xie, P.F. (2012) Socio-economic impacts of birdwatching along Lake Erie: a coastal Ohio analysis. Research report. Bowling Green State University.

Ziv, G., Baran, E., Nam, S., Rodríquez-Iturbe, I., \& Levin, S.A. (2012) Trading-off fish biodiversity, food security, and hydropower in the Mekong River Basin. Proceedings of the National Academy of Sciences, 109, 5609-5614.

Ziv, G., Mullin, K., Boeuf, B., Finchman, W., Taylor, N., Villalobos-Jiménez, G., ... Beckmann, M. (2016) Water quality is a poor predictor of recreational hotspots in England. PLoS One, 11, e0166950. 
Table 1. A glossary of key terms used throughout the manuscript.

\begin{tabular}{|c|c|}
\hline Term & Definition \\
\hline Dispersal limitation & $\begin{array}{l}\text { A species cannot reach all suitable sites in a region because of } \\
\text { too long spatial distances or physical obstacles. At the local } \\
\text { community level, dispersal limitation may result in the absence } \\
\text { of many species that could be expected to occur therein based } \\
\text { on prevailing environmental conditions (Heino et al., 2015). }\end{array}$ \\
\hline Drainage lake & $\begin{array}{l}\text { A lake having surface water connections to other lakes via } \\
\text { streams or rivers. }\end{array}$ \\
\hline Dynamism & $\begin{array}{l}\text { The tendency of environmental conditions and biological } \\
\text { communities to vary in time and space (Datry et al., 2016). }\end{array}$ \\
\hline Floodplain lake & $\begin{array}{l}\text { A lake connected to the river by recurring flooding in the rainy } \\
\text { season. Often lack connections to the river during the dry } \\
\text { season. }\end{array}$ \\
\hline Land-locked lake & $\begin{array}{l}\text { A lake with no surface water connection by streams or rivers to } \\
\text { other lakes in a drainage basin. }\end{array}$ \\
\hline Lake & $\begin{array}{l}\text { A standing water body with a surface area greater than two } \\
\text { hectares (Williams et al., 2004). Smaller standing water bodies } \\
\text { are considered ponds and pools. }\end{array}$ \\
\hline Lake order & $\begin{array}{l}\text { Lake order is a measure of a lake's relative position in the } \\
\text { landscape. It can be easily measured from maps, providing a } \\
\text { proxy for connectivity and variation in physical, chemical and } \\
\text { biological features of lakes in the landscape. Lake order varies } \\
\text { from isolated lakes with no surface water connections (negative }\end{array}$ \\
\hline
\end{tabular}


values) to drainage lakes with inlets and outlets (positive

values). It is thus based on examination of hydrologic inputs

through ground water, terrestrial inputs through surface waters,

and among-lake connections via streams and rivers (Riera et

al., 2000).

Large lake system

A very large lake (more than $500 \mathrm{~km}^{2}$ in surface area;

Herdendorf, 1982), with often highly irregular shoreline and

comprising a number of separate bays. Examples include Lake

Saimaa in Finland, Lake Ladoga in Russia and Lake Taihu in

China. Also, the Great Lakes of North America belong to this

class of lakes.

Metacommunity

A set of local communities connected by the dispersal of

species (Leibold et al., 2004). For example, a set of lakes in a

drainage basin equals to a lake metacommunity.

Meta-ecosystem

A set of individual ecosystems connected by the movements of

organisms and material between locations (Loreau et al., 2003).

A meta-ecosystem can comprise connected lakes in a

watercourse or interactions between a lake and its riparian

zone.

Non-stationarity

Posits that natural systems fluctuate within a changing

envelope of variability (Milly et al., 2008). Emphasizes non-

linear change due to anthropogenic impacts. Challenges

assumptions of attainment of historical reference conditions

due to changing baselines. 
Recovery

Resilience

Species sorting

Watercourse lake

Waterscape
The tendency of a lake to return to its original (or at least to a previous good) environmental and biological conditions after a disturbance. This view is rooted in the balance-of-nature view, traditionally embraced in ecological stability research (Allen et al., 2019)

The amount of disturbance needed to shift an ecosystem from one set of ecological structures, functions and feedbacks to another set (Holling, 1973). Inherent in this definition are thresholds, non-linear and often abrupt changes to alternative regimes from which a return to a previous regime is impossible due to stabilizing effects of feedbacks (Baho et al., 2017). In species sorting, sufficient dispersal allows species to track variation in local abiotic and biotic conditions, resulting in a good match between biological communities and the environment (Leibold et al., 2004).

A lake connected to other lakes by streams or rivers. A set of lake sites in a regional setting, where physical, chemical, biological and societal factors determine both the regional and local dynamics underlying variation in biodiversity and ecosystem services. 
Table 2. Selected examples of studies focussing on the ecosystem services provided by freshwater ecosystems.

\begin{tabular}{|c|c|}
\hline Example & Description \\
\hline Monetary value & $\begin{array}{l}\text { The average monetary value of the ecosystem services provided } \\
\text { by lakes has been estimated to be } 4267 \$ \text { ha }^{-1} \text { year-1 }^{-1} \text { (de Groot et } \\
\text { al., 2012). This estimate was based on a very low number of case } \\
\text { studies with poor spatial coverage ( } 15 \text { studies in total, } 2 \text { to } 8 \text { case } \\
\text { studies for values of each ecosystem service). Therefore, the } \\
\text { monetary value estimates of lake ecosystem services by de Groot } \\
\text { et al. (2012) should be used with caution because they are } \\
\text { statistically and spatially unrepresentative at present. }\end{array}$ \\
\hline Recreational fisheries & $\begin{array}{l}\text { Recreational fisheries have locally high relative importance in } \\
\text { providing employment. For example, the fishery of the Spey } \\
\text { catchment in Scotland contributes } 11.6 \text { million } £ \text { annually to the } \\
\text { local economy and supports } 401 \text { full time jobs (Butler et al., } \\
2009 \text { ), whereas freshwater anglers spend over } 1.114 \text { billion } £ \text { in } \\
\text { the UK (Winfield, 2016). }\end{array}$ \\
\hline Outdoor activities & $\begin{array}{l}\text { Outdoor activities, such as swimming, canoeing, wind surfing, } \\
\text { boating, cruise-tourism, bird watching and holidaying, are } \\
\text { considered important for human well-being and enhance local and } \\
\text { regional economies. As an example, this trend was also shown in } \\
\text { the assessment of the coastal ecosystem services in the Nordic } \\
\text { countries which had a marine focus but also included case studies } \\
\text { from rivers and lakes (https://www.norden.org/fi/node/7618). }\end{array}$ \\
\hline
\end{tabular}


Holocene lake sediments have been estimated to contain $820 \mathrm{Pg}$ buried organic carbon worldwide (Tranvik et al., 2009). This concentration is almost twice as high as the shorter-term carbon sink comprising the terrestrial plant biomass ( 460 Pg; Cole et al., 2007), but lower than carbon storage of terrestrial soils ( 1 395 Pg). In Finland, lakes contain the second largest areal C stocks (19 $\mathrm{kg} \mathrm{C} \mathrm{m}{ }^{-2}$ ) after peatlands ( $\left.72 \mathrm{kgCm}^{-2}\right)$, and exceed by significant amounts stocks in the forest soil (uppermost $75 \mathrm{~cm} ; 7.2 \mathrm{~kg} \mathrm{C} \mathrm{m}^{-2}$ ) and woody biomass (3.4 $\left.\mathrm{kg} \mathrm{C} \mathrm{m}^{-2}\right)$ (Kortelainen et al., 2004). Relative organic carbon burial capacity is especially high for small lakes and for lakes with large catchments (Downing et al., 2008). Despite their relatively small surface area $(\sim 3 \%$ of the Earth's surface, Downing et al., 2006), freshwater lakes have also been estimated to contribute from 6 to $24 \%$ of the global methane release, a highly potent greenhouse gas (Bastviken, Cole, Pace \& Tranvik, 2004; Bastviken, Tranvik, Downing, Crill \& Enrich-Past, 2011). 
Fig. 1. A schematic overview of the differences among major lakes types with regard to regional dynamics of the movements of organisms and material between locations. 